\title{
Hajj Pilgrimage and the New Emerging Cases of Middle East Respiratory Syndrome Outside the Middle East
}

\author{
Viroj Wiwanitkit ${ }^{1,}$ \\ ${ }^{1}$ Graduate School Public Health Curriculum, Surin Rajabhat University, Surin, Thailand \\ ${ }^{*}$ Corresponding author: Viroj Wiwanitkit, Graduate School Public Health Curriculum, Surin Rajabhat University, Surin, Thailand. Tel: +66-24132436, Fax: +66-24132436, E-mail: wvi- \\ roj@yahoo.com \\ Received 2015 August 13; Revised 2015 September 23; Accepted 2015 September 28.
}

Keywords: MERS, Pilgrimage, Emerging

\section{Dear Editor,}

Emerging infectious disease is an important issue in health scope and problematic in public health. Within the past few years, many new and problematic infections have emerged in the world. Middle East Respiratory Syndrome (MERS) is a new emerging infection that was firstly detected in the Middle East and since then several epidemics have been reported in other areas (1). The occurrence of MERS outside the Middle East has become a global public health issue.

For any new emerging infection, the mode of transmission is usually the significant issue in medicine. There is also a common concern on the transmission of disease in the situations with crowded population. The gathering of a large group of people during the annual pilgrimage period (such as in India and Saudi Arabia) is usually accused as a starting point for disease outbreak (2).

Figure 1. Geographical Distribution of the MERS in 2015 Outbreak

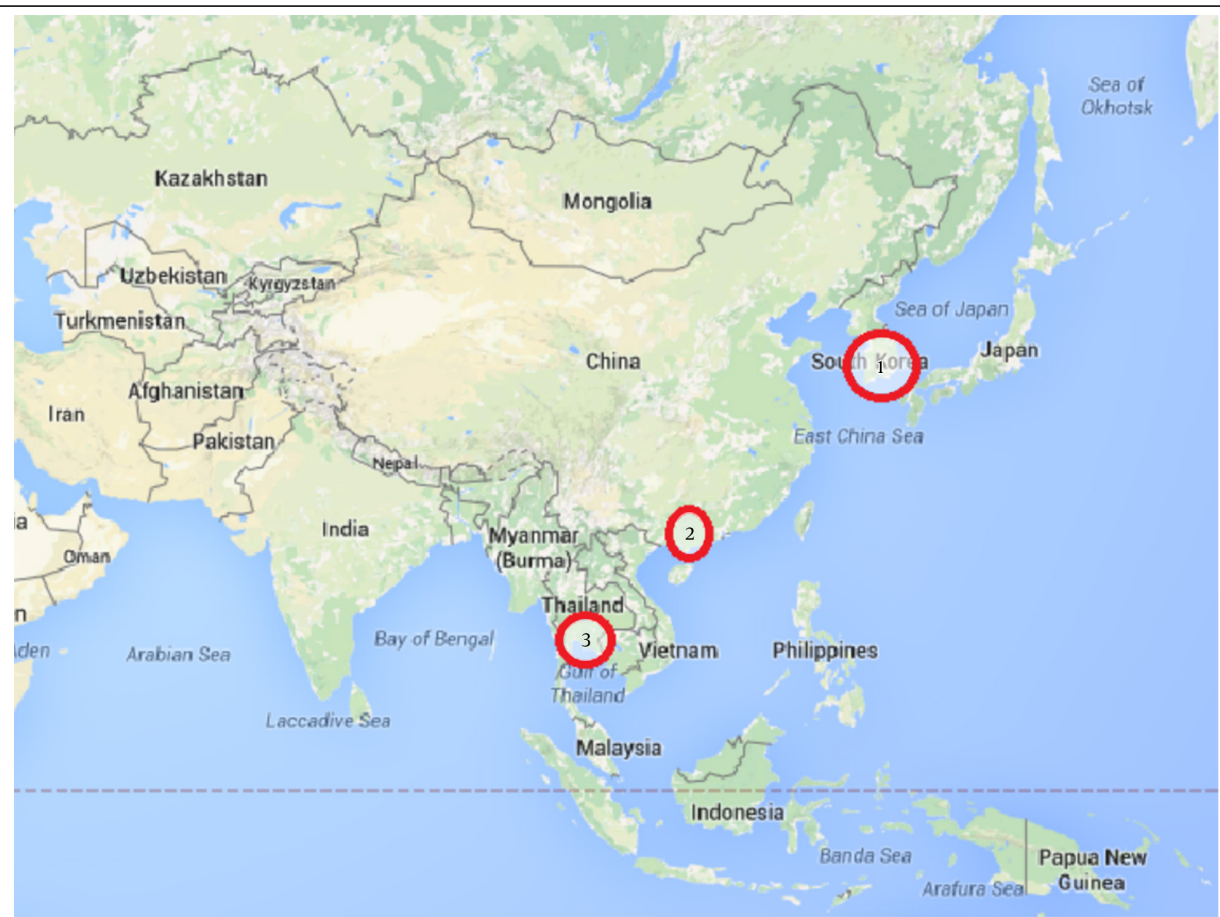

1, Seoul, South Korea, the first case was a Korean contracted disease after returning from a business trip in the Middle East (May 2015); 2, Guangdong, China, the first case was a Chinese contracted disease after visiting his friend in South Korea (May 2015); 3, Bangkok, Thailand, the first case and only one case was a foreigner from Oman who carried the disease from the Middle East (June 2015).

Copyright (C) 2016, Health Promotion Research Center. This is an open-access article distributed under the terms of the Creative Commons Attribution-NonCommercial 4.0 International License (http://creativecommons.org/licenses/by-nc/4.0/) which permits copy and redistribute the material just in noncommercial usages, provided the original work is properly cited. 
Table 1. Pattern of the MERS in the First Year of Its Detection Along With the Trend of Disease in the Following Years

\begin{tabular}{ll}
\hline Year & \multicolumn{1}{c}{ Trend } \\
\hline $\mathbf{2 0 1 2}$ & $\begin{array}{l}\text { The first case was reported in Saudi Arabia along with } \\
\text { some sporadic cases in the Middle East. }\end{array}$ \\
\hline $\mathbf{2 0 1 3}$ & $\begin{array}{l}\text { A large outbreak was seen in Saudi Arabia and there } \\
\text { was a new emerging disease in Europe. WHO called } \\
\text { for attention of the global threat of MERS. }\end{array}$ \\
$\mathbf{2 0 1 4}$ & The first case was seen in the USA. \\
\hline $\mathbf{2 0 1 5}$ & $\begin{array}{l}\text { New emerging disease occurred in South Korea and } \\
\text { there was a large epidemic in South Korea. Also, } \\
\text { sporadic emerging infections are seen in China and } \\
\text { Southeast Asia (Thailand and the Philippines) }\end{array}$ \\
\hline
\end{tabular}

This is also the case for the MERS. Since the original site of MERS was the Middle East, the Hajj pilgrimage is usually mentioned for the possible spread of the disease to other areas. However, this accusation seems to be wrong. Regarding the 2015 outbreak of MERS in Korea, China, and Thailand, there was no evidence of imported cases of MERS from Hajj or other Islamic pilgrimage visit to the Middle East $(3,4)$ (Figure 1 ). In addition, many cases of MERS have been reported in non Middle East areas, and there was only one case reported in Malaysia that had an evidence of rela- tionship to Hajj (5) (Table 1). Hence, it should be noted that Hajj pilgrimage is not the common detected problem in new emerging cases outside the Middle East. Good preparation and strict sanitation practice during pilgrimage visit can guarantee the safety of this practice (6).

\section{References}

1. Zumla A, Hui DS, Perlman S. Middle East respiratory syndrome. Lancet. 2015;386(9997):995-1007. doi: 10.1016/S01406736(15)60454-8. [PubMed: 26049252]

2. Landry P, Slama S. Pilgimage and other mass gatherings: epidemiology and prevention [in French]. Rev Med Suisse. 2008;4(157):1192-5. [PubMed: 18561823]

3. Khan A, Farooqui A, Guan Y, Kelvin DJ. Lessons to learn from MERSCoV outbreak in South Korea. J Infect Dev Ctries. 2015;9(6):543-6. doi:10.3855/jidc.7278. [PubMed: 26142661]

4. Ling Y, Qu R, Luo Y. Clinical analysis of the first patient with imported Middle East respiratory syndrome in China [in Chinese]. Zhonghua Wei Zhong Bing Ji Jiu Yi Xue. 2015;27(8):630-4. doi 10.3760/cma.j.issn.2095-4352.2015.08.002. [PubMed: 26255008]

5. Memish ZA, Zumla A, Alhakeem RF, Assiri A, Turkestani A, Al Harby KD, et al. Hajj: infectious disease surveillance and control. Lancet. 2014;383(9934):2073-82. doi: 10.1016/S0140-6736(14)603810. [PubMed:24857703]

6. Premila Devi J, Noraini W, Norhayati R, Chee Kheong C, Badrul AS, Zainah S, et al. Laboratory-confirmed case of Middle East respiratory syndrome coronavirus (MERS-CoV) infection in Malaysia: preparedness and response, April 2014. Euro Surveill. 2014;19(18). [PubMed: 24832116] 